\title{
DIE VERHOUDING VAN BELYDENIS TOT OPENBARING IN DIE BOEK JESAJA
}

\author{
J.L. Helberg \\ Departement Ou Testament \\ Potchefstroomse Universiteit vir $\mathrm{CHO}$ \\ POTCHEFSTROOM
}

\begin{abstract}
This article offers an investigation of the relation of human confession to divine revelation in the book Isaiah. Aspects like the character and place of confession, the content of God's revelation and of Israel's confession, the grounds, driving force, the function and aim of Israel's confession are discussed. The findings are that God's initiative in his action and in his word is dominant; confession has a modest, subordinate place in relation to divine revelation. Confession is concemed with what God does and says and is a confinmation of it and not a new, independent consideration.

Israel had to hear or listen, they had to take heed of God's will regarding their life in totality. This requirement is stressed in first instance, and not confession. Confession should be an embodiment of the former and is worhless without it. The ain of confession is not the worshipping of a nane or characteristic of God, but the worshipping of God Himself. Confession acknowledges and praises God because of what He is - the only God: Creator, Ruler and Saviour.
\end{abstract}

\section{INLEIDING}

Die doel van hierdie artikel is om vas te stel wat die boek Jesaja oor belydenis sê en om die verhouding van belydenis tot openbaring in dié boek te bepaal.

Dit val buite die bestek van hierdie artikel om op die vraag in te gaan of die Ou Testament as geheel nie belydenis is nie, belydenis by wyse van bespiegeling oor God se openbaring en/of ervaring van God se openbaring (vgl. bv. Deist, 1982:30; Von Rad, 1962:4,121-126; Helberg, 1983:26,27,58,59; Childs, 1979:58,59,123-125).

Die artikel sal aantoon dat die boek Jesaja volledig teosentries is: God word as middelpunt en doelpunt van alles gestel, ook as die uitgangspunt van alles. Hy het alle inisiatief en Hy bestier alles. Hierdie teosentriese benadering het 'n deurslaggewende betekenis in die verhouding van belydenis tot openbaring. Om hierdie verhouding te kan bepaal, moet die aard en plek van belydenis in Jesaja vasgestel word, asook die inhoud, die grond en dryfveer sowel as die funksie en doel. Aan die einde sal die 
implikasies van die studie vir die benadering van 'n kerklike belydenis of belydenisskrif aangedui word.

Die boek Jesaja word as 'n eenheid beskou omdat dié boek, ondanks sekere verskille tussen hoofstuk 1-39, 40-55 en 56-66, tog 'n besliste eenheid vorm. Hierdie eenheid kom byvoorbeeld na vore in die naam "die Heilige van Israel" wat in al die gedeeltes van die boek en byna uitsluitlik in hierdie boek voorkom. Hierdie benaming vorm nie net 'n formele binding in die boek nie maar gee ook uitdrukking aan 'n inhoudelike eenheid wat handel oor die optrede van God as die Heilige van Israel. Die eenheid van die boek word verder genoegsaam deur Childs (1979:325-334) beredeneer, sodat dit nie ook hier nader beredeneer hoef te word nie. Beuken (1983:183) wil ondanks ponering van 'n duidelike verskil tussen 40-55 en 56-66 nie van 'n sekere eenheid afsien nie. Tog sal daar wel nagegaan word of tie onderskeie gedeeltes onderlinge verskille vertoon en indien wel, wat die implikasies daarvan vir ons onderwerp is.

\section{DIE AARD EN PIEK VAN BEI.YDENIS}

Dit is 'n kenmerk van die Ou Testament as geheel dat belydenis veral in lofsegging voorkom en dan veral handel oor die dade van God (vgl. Young, 1972a: 406 oor Jes. 12:4). Net soos die geskiedenis van die uittog uit Egipte bekroon word deur die lied van die Rietsee (Eks. 15), so word die redding hier deur 'n loflied opgevolg (vgl. Kaiser, 1970:134; Snijders, 1969:152). Israel moet van God se genade en liefde getuig; nie van hulle eie werke of prestasies nie (vgl. Young, 1972b: 158 oor 43:21). Op grond van die feit dat die psalmdigters hulle geloof in 'n digterlike idioom uitgedruk het, maak Terrien (1978:337) die te eensydige afleiding dat 'n geloofsbelydenis gesing moet word as 'n doksologie en nie geteken moet word as 'n onderrigtende of wetlike dokument nie. Von Rad (1962:140) praat in soortgelyke terme oor die skepping: onderrig het 'n funksie gehad maar van ' $n$ meer verborge aard en het in diens van lofsegging gestaan. Westermann (1978:140) wys daarop dat dit in die religie van Israel nooit tot 'n verselfstandiging van die kultus of die leer gekom het nie. Die verhouding met God het deur die hele geskiedenis heen 'n lewende wisselwerking ingehou en is telkens bepaal deur nuwe belewenisse in die steeds veranderende lewe.

In die openbaringshistoriese gegewens oor ingrypende gebeurtenisse in die res van die Ou Testament het menslike belydenis nie 'n prominente plek nie. Voorbeelde hiervan is die skepping en die Paradys (Gen. 1-3), die roeping van Abraham (Gen. 12), die verbondsluiting met Abraham (Gen. 15,17), die verbondsluiting met Israel, die gee van die Tien Gebooie (Eks. 20,24) en die totstandkoming van die nuwe verbond (Jer. 31:31-37). Hierdie optrede van God het nie 'n menslike antwoord in die vorm van 'n belydenis oor God as teenpool nie en word nie daardeur opgevoly nie. Dit is selfs nie 
die geval by die verbondsluiting, waarin daar so ' $n$ noue verbinding bewerk word tussen God en sy volk nie. Die hele fokus is gerig op wat God doen. Die mens is nie werklik 'n "vennoot" van God nie - inteendeel, die reaksie wat in bogenoemde gevalle van die mens verwag word, is om God se wil uit te voer in gehoorsame optrede. Wanneer God aan Dawid ' $n$ blywende dinastie belowe (2 Sam. 7) en wanneer die tempel ingewy word deur Salomo (1 Kon. 8), is daar wel iets soos 'n belydenis deur Dawid en Salomo. Dit is egter meer 'n spontane gebed en lofprysing asook 'n toespraak.

In ooreenstemming met bogenoemde het belydenis ook 'n beskeie plek in Jesaja. Daar is weinig kere direk sprake van 'n belydenis. Die belydenis kom veral voor as 'n lofsegging aan God of as oproep om God te loof. ${ }^{1}$ Ook die hemel en die aarde word opgeroep om 'n belydenis te doen. ${ }^{2}$

Om die plek en aard van belydenis in Jesaja te bepaal, kan ons veral aansluit by twee kenmerkende begrippe in die boek, naamlik ken (רירע) en hoor of luister (שמע). Schult $(1976: 979,980)$ wys daarop dat God nêrens in die Ou Testament gevra word om die lof van die aanbidders te "hoor" nie. God as hoorder het oorwegend te doen met die mens se roep, skreeu, klaag, ween, bid, wens. Sy "hoor" is help en red. Sy nie-hoor is om die bidder te ignoreer en aan homself oor te laat (Jes. 59:1). Hoor is dus tegelykertyd om te reageer en veronderstel 'n wedersydse optrede. So is dit ook met die mens se "hoor" - dit slaan veral op gehoor gee aan God se gebooie. Sonder dade is mooi woorde waardeloos en selfs 'n uiting van skynheiligheid (vgl. 58:1-4).

Om die Here te "ken", druk nie net intellektuele kennis uit nie maar veral 'n praktiese, religieus-sedelike verhouding (vgl. Botterweck, 1982:499,500; Schottroff, 1971:690,695). Om God te ken, sluit dus ook in om Hom te erken en dit kan ook insluit om Hom te bely (52:6). God bestraf sy volk omdat hulle Hom nie ken nie en nie na Hom of na die verkondiging oor Hom luister nie. ${ }^{3}$ Hulle toon geen begrip van wat $\mathrm{Hy}$ as Vader vir

${ }^{1}$ 63:17: "Ek sal die Iroue liefde van die Here verkondig, dic rocmryke dade van dic Here, alles wat Hy vir ons gedoen het, sy grootheid en gocdheid vir Israel, alles wat Hy gedoen het in sy genade, in sy groot liefde ..."; 12:4-6: "Op dié dag sal julle uitrocp: Lool die Here, roep sy Naam aan, maak sy dade onder die volke bekend en verkondig dat sy Naam grool is. Sing lot dic eer van die Here, want Hy het groot dinge gedoen, maak dit aan die hele wêreld bekend. Jubel en juig, inwoners van Sion, want groot is die Heilige van lsrael en Hy is by julle!"; 42:12: "Laat hulle aan die Here eer bewys en op die cilande sy lof verkondig"; 43:21: "Dit is die volk wat Ek geskep het, en wat my lof sal verkondig"; 52:6: "Daardie dag sal my volk my Naam bely: dat Ek dic Here is, dat dit Ek is wat sê: Hier is Ek!"

2 44:23: "Juig, hemel, oor wat dic Here gedoen het, jubel dieptes van die aarde, wees bly en juig. berge en bosse, want die Here het vir Jakob, vir Israel, verlos, dic Here het sy mag laat blyk."

${ }^{3}$ 1:3: "Ek het kinders grootgemaak en opgevoed, maar hulle het teen my in opstand gekom. 'n 
hulle gedoen het nie. Hulle luister ook nie na sy profete en na die verkondiging van sy skepping nie en weet ( ידע ) daarom nie dat Hy die Skepper en Regeerder is nie. ${ }^{4}$ Israel word bestraf oor sy optrede en word opgeroep om te luister. 5 God stel nie belang in hulle offers en hulle feeste nie (1:11-14). Hy aanvaar selfs nie hulle gebed nie (1:15), want hulle laat nie reg geskied nie (1:17). Hy is die Een wat sê of praat $(1: 20 ; 40: 5)$, húlle moet gehoor gee, gehoorsaam wees (1:19), op Hom vertrou (1:31). Deur sy reddende optrede sal Hy hulle laat besef (ירע) dat Hy Jahwe, hulle Verlosser is $(60: 16)$.

Die plek en aard van belydenis in Jesaja word dus bepaal deur dit waarom dit ten diepste gaan: dit is God wat sê, wat verkondig; sy volk moet luister en gehoor gee deur sy woord te gehoorsaam, op Hom te vertrou en daarvolgens te lewe. Die menslike spreke en belydenis is nie uitgesluit nie maar het 'n beskeie en dienende plek. Dit kom onder meer na vore in die inhoud, die grond en die dryfveer van belydenis in Jesaja.

\section{DIE INHOUD VAN DIE OPENBARING EN VAN DIE BELYDENIS}

Die boek Jesaja gebruik ' $n$ verskeidenheid name en omskrywinge en dui daarmee ' $n$ wye spektrum van hoedanighede van God aan. (Vir meer besonderhede hieroor en vir tersaaklike literatuurverwysings, kyk Helberg, 1988a:64-66; 69-73). Hierdie name en omskrywinge word veral deur God verkondig, maar hulle word ook deur Israel gebruik om Hom te bely. Verder in die artikel word sommige name wat vir ons onderwerp belangrik is bespreek. Die doel van hierdie bespreking is om vas te stel wat die inhoud van die Goddelike openbaring en van die belydenis van Israel onderskeidelik is en wat die verhouding daartussen is.

Bees ken sy eienaar en 'n donkie die krip van sy baas, maar Israel ken My nie, my volk het geen begrip van wat Ek doen nie".

4 40:21,28: "Weet julle dan nie, het julle nie gehoor nic, is dit nie van die begin af aan julle bekend gemaak nie, het julle nie 'n begrip van hoe die aarde ontstaan het nie? God het sy troon bokant die hemelkoepel, die aardbewoners is vir Hom soos sprinkane ... Weet jy dan nie, het jy nog nic gehoor nie? Die Here is die ewige God, Skepper van die hele aarde. Hy word nic moeg nie, Hy rak nie afgemat nie en sy insig is ondeurgrondelik."

5 1:10: "Luister na die woord (tora) van die Here, jullc Sodomsleiers! Gee ag op wat ons God ons leer, julle Gomorrasvolk!" 


\subsection{Verbond en verkiesing}

Behalwe in gedeeltes wat met die ballingskaptyd of die tyd daarna verband hou, 6 word die woord "verbond" in die boek Jesaja vermy. Dit is nie 'n bewys dat die verbondsbegrip eers in die ballingskap ontstaan het, soos sommige geleerdes meen nie (vgl. oor hierdie problematiek Wildberger, 1982:1595,1596; vgl. ook Barr, 1974:13-18; Bright, 1976:40-42), maar is toe te skryf aan die volk se valse assosiasies met die verbond, asof dit hulle verhouding met God en hulle welsyn outomaties gewaarborg het. Vir die volk wat reeds deur die vuurproef gegaan het, ${ }^{7}$ kan die fokus weer gevestig word op God se genade soos in sy verbond met sy volk beliggaam. Dat Israel in 'n verhouding van verbond en verkiesing staan, word wel duidelik gestel deurdat God praat van "my volk", 8 en die profeet praat van "ons God"9, "die God van Jakob"10 ."u volk"11 en "sy volk"12. Die verkiesing van Israel word duidelik gestel13. In die eerste gedeelte van die boek word die begrip in 14:1 gebruik en wel in noue verbinding met Jahwe se ontferming oor "Jakob" - 'n benaming waarin ondertone van verbond en verkiesing gehoor word (vgl. Delitzsch, 1949:162,163; Smart, 1967:71,72; Knight, 1984:30; North, 1967:97). In 65:9 en 15 word die begrip in die vorm van 'n selfstandige naamwoord (בחרים) gebruik as parallel vir "dienaars". Daarmee word 'n verskil binne die volk self gemaak.

Teenoor die volk se formalistiese benadering wat 'n soort outomatiese werking aan die kultus, verbond en verkiesing toeskryf, word God se vrye inisiatief benadruk. ${ }^{14}$ Jesaja bely God se ontferming, barmhartigheid, goedheid en troue liefde. 15

\footnotetext{
${ }^{6} 55: 3 ; 56: 4,6 ; 59: 21 ; 61: 8$.

${ }^{7} 40-66$.

$81: 3 ; 3: 12,15 ; 5: 13 ; 10: 24 ; 40: 1 ; 43: 20 ; 47: 6 ; 51: 4,16 ; 52: 4,5,6 ; 53: 8 ; 57: 14 ; 58: 1 ; 63: 8 ; 65: 10,19,22$.

${ }^{9} 1: 10$

${ }^{10} 2: 2$

$112: 6 ; 63: 14,18 ; 64: 9(H=8)$.

$123: 14 ; 5: 25 ; 11: 11,16 ; 25: 8 ; 30: 26 ; 49: 13 ; 51: 22 ; 52: 9 ; 56: 3 ; 63: 11$.

$1341: 8,9 ; 43: 10,20 ; 44: 1,2 ; 49: 7$.

14 30:18: Tog is die Here gretig om julle genadig te wees en wil Hy Hom oor julle ontferm"; vgl ook 37:32; 65:1,2,24.

$1525: 4 ; 63: 7,9$.
} 
God word in Jesaja baie sterk met reg en geregtigheid verbind. 16 Tog is sy genade en ontferming so beheersend dat die woord geregtigheid (צ̧ךָָ) dikwels in Jesaja gebruik word om God se verlossende optrede vir sy volk aan te dui, en wel 'n verlossing wat sonder enige verdienste van hulle kant geskied. ${ }^{17}$

In al die gedeeltes van Jesaja verkondig God Homself dus, en word Hy bely as die God wat in ' $n$ verhouding van verkiesing en verbond met sy volk staan waarin Hy vrymagtig is, alle inisiatief het, bekering en gehoorsaamheid eis en in genade en liefde optree.

\subsection{Woord en geskiedenis}

God tree op deur sy woord; sy woord is effektief. As Hy straf of verlossing vir sy volk aangekondig het, is dit die waarborg dat dit sal gebeur $(1: 20 ; 25: 8 ; 40: 5 ; 58: 14)$. Dit gebeur egter nie outomaties nie, want God bly ten volle en persoonlik in beheer daarvan (vgl. Vriezen, 1966:30:31; Young, 1972b:384). Bowendien het sy verkondiging bekering ten doel. In hierdie sin is die betekenis dus voorwaardelik. Die vloek word afgeweer as daar bekering is (vgl. Verhoef, 1981:45). God se woord keer nie onverrigter sake na Hom toe terug nie, maar bewerkstellig verlossing vir sy volk (55:3, 8-11). As Hy iets sê, neem dit 'n aanvang in gebeurtenisse, geskiedenis (Westermann, 1966:36). Die profeet bely dat die woord van God vir ewig bly (40:8) - sy beloftes staan vas. Hy voer uit wat Hy lankal besluit het (25:1), daar kan altyd op Hom vertrou word $(26: 3,4)$. God regeer oor alles; Hy bepaal ook die toekoms; daarom verkondig Hy ook wat sal gebeur $(42: 9 ; 44: 7 ; 45: 11)$. Hieruit kan afgelei word dat God die geskiedenis beheer; Hy doen dit deur sy woord, sy woord wat onweerstaanbaar en effektief is en tog die,mens nie tot 'n blote onpersoonlike outomaat of klankbord mak nie. In antwoord op sy reddende optrede bely sy volk Hom as hulle God, die God op wie hulle vertrou, die God wat inderdaad red (25:9).

\footnotetext{
16 5:16; 30:18.

${ }^{17} 45: 8,24 ; 46: 12,13 ; 48: 18 ; 51: 6,8 ; 56: 1 ; 61: 11 ; 63: 1$.
} 


\subsection{Koning}

God noem Homself Koning, en Jesaja bely hom so. ${ }^{18}$ Die aanduiding Koning verwys na sy almag en seggenskap as Skepper en Regeerder en sê dat Hy die enigste God en sy volk se Verlosser is (vgl. ook Beuken, 1979:96). Muilenburg (1956:193) merk by 43:15 op dat die begrip "julle koning" die gedagte vestig op Israel se nood in die huidige wêreldsituasie. In 65-66 kom die aanduiding Koning vir God nie voor nie maar daar word wel gesê dat die konings van die nasies Hom en sy volk sal eer; Hy sal geëer word as die Magtige van Jakob, die Heilige van Israel $(60: 7,9,14,16)$.

Hoewel die woord koning dikwels in die Ou Testament voorkom, word dit baie min in verband met God gebruik. Dit is moontlik gedeeltelik toe te skryf aan die assosiasies met die onaanvaarbare heidense koningskap van die buurnasies (vgl. Soggin, 1971:909,915,916). Die koningskap is bowendien 'n laat en sekondêre instelling in Israel se geskiedenis en het ná die ballingskapstyd prakties verdwyn as instelling met selfstandige gesag, onafhanklik van ander oorheersers, en dit sonder dat Israel se godsdienstige bestaan daardeur grondliggend geraak is. God se heerskappy strek veel verder, hoër en dieper as wat die assosiasie met koningskap alleen kan weergee; Hy is trouens die Skepper en Regeerder van die hemel en die aarde (vgl. ook Seybold, 1984:951). Teenoor Hom pas die belydenis dat Hy almagtig en vrymagtig is, die God wat getrou is en red.

\section{$3.4 \quad$ Vader}

Hoewel God Homself nie uitdruklik Vader noem nie, impliseer Hy dit duidelik in 1:2.19 Namens die volk beroep die profeet hom in 63:16 voor God daarop dat Hy hulle vader is. ${ }^{20}$ In hierdie naam en omskrywing word God se seggenskap en heerskappy oor sy volk, sowel as sy sorg, beskerming en verlossing vir sy volk, aangedui (vgl. ook

\footnotetext{
18 43:14,15: "So sê die Here, julle Verlosser, die Heilige van Israel ... Ek is die Here, julle heilige God, dic Skepper van Isracl, julle Koning"; 44:6 (vgl. ook 52:7): "So sê die Here, die Koning van Israel, Sy Verlosser, dic Here die Almagtige: Ek is die eerste en Ek is die laaste, buiten My is daar geen God nie"; 6:5: "En nou het ek die Koning gesien, die Here die Almagtige"; 33:22: "Die Here is ons Regler, die Here is ons Leidsman, die Here is ons Koning. Hy sal ons red."

19 "Ek het kinders grootgemaak en opgevoed, maar hulle het teen My in opstand gekom."

20 " $\mathrm{U}$ is $\log$ ons vader. Abraham weet niks van ons nie cn Israel is nie van ons bewus nie; $U$, Here, is ons vader, van ouds af is u Naam: Ons Verlosser".
} 
63:17). In 64:8 word God se hoedanigheid as Vader parallel gebruik met sy hoedanigheid as Formeerder, Skepper. ${ }^{21}$ 'n Soortgelyke gebruik kom voor in 45:11.22 Beuken (1979:168) wys dan ook in verband met 43:7 op die noue verband tussen Skepper en Vader in die Ou Testament (vgl. ook Deut. 32:6; Mal. 2:10). Hier is egter geen sprake van fisiese vaderskap soos by die mitiese beskouing van Israel se bure nie: die mens is 'n skepsel (vgl. Westermann, 1966:312; Jenni, 1971a:14). Die verhouding van Israel tot Jahwe is dié van aanneming (Scott, 1956:167).

In 40-55 word die klem egter enersyds baie sterk gelê op God as Skepper, en andersyds op Israel se rol om dienaar van die Here te wees. ${ }^{23}$ Daarmee word die klem baie sterk gelê op Israel se algehele afhanklikheid van God om presies te doen wat Hy bepaal en vereis, soos dit veral uitkom in die sogenaamde knegliedere wat op Israel en tegelykertyd op iemand meer as Israel slaan. ${ }^{24}$ Dienaarskap word hier parallel met verkiesing deur God gebruik en benadruk dat Israel nie uit eie keuse of verdienste dienaar is nie, maar alleen deur God se genade in diens geneem is en volkome volgens sy wil moet leef (vgl. Young, 1972b:81). Ook die bystelling "afstammeling van Abraham vir wie Ek

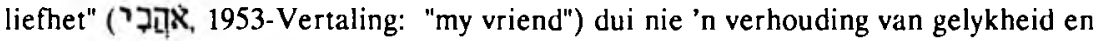
van wedersydse toegeneentheid en hulp aan nie. Omdat die Here Abraham uitverkies het, was hy tot lojaliteit in staat (vgl. Beuken, Muilenburg, 1956:454,455). Om dienaar te wees, impliseer dus om geborge te wees, op God te kan vertrou vir sy sorg en om Hom te dien (vgl. Westermann, 1966:59). Die klem val dus op Israel se algehele menslike diensbaarheid aan God en hierdie diensbaarheid berus nie op wat Israel oor God bely nie, al het belydenis oor God daarin 'n besliste plek (44:1-5).

\subsection{Die Here die Almagtige (Jahwe Sebaot)}

Hierdie Naam word dikwels gebruik in verbindinge wat God se mag en heerskappy aandui en kom dikwels in Jesaja voor, 25 hoewel nie in 56-66 nie.

\footnotetext{
21 " $U$ is ons Vader, Here, ons is klei en $U$ het ons gevorm, ons is almal dic werk van u hande."

22 "So sé die Here, die Heilige van Israel, dic Skepper van Israel ... Durf julle aan My voorskryf oor my kinders en oor dic werk van my hande?"
}

${ }^{23} \mathrm{Vgl}$. bywoorbecld $41: 8 ; 42: 19 ; 44: 1,2,21 ; 45: 4 ; 48: 20$.

$24 \mathrm{~V}_{\mathrm{gl}}$. byvoorbeeld $42: 1 ; 49: 3,6 ; 50: 10 ; 52: 13 ; 53: 11 ;$ vgl. Beuken, 1979:118,119; 1983:9,10,93,94,185, 186,237-241. Beuken verklaar die kneg in 52:13-53:12 kollektief.

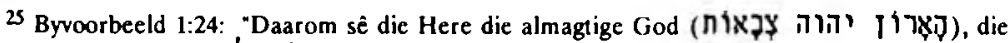
Sterke van Israel (אכ) : Ek sal afreken met my teêstanders. Ek sal My wreck op my vyande"; 44:6: "So sê die Here, die Koning van Israel, sy Verlosser, die Here die Almagtige: 
Snijders (1969:39) wys daarop dat Jahwe Sebaot in Jesaja (1-39) steeds in tekste voorkom wat iets laat hoor oor 'n strydende en oordelende Jahwe. Hy is in beheer van alles. "Die Here die Almagtige" is die aanvaarbaarste vertaling van יהוה צִ (vgl. Van der Woude, 1976:505; kyk ook Zobel, 1989:892; Elliger, 1978:401; Kaiser, 1970:61) en dui in Jesaja God se unieke koninklike heerskappy en mag aan, sy mag om te straf ${ }^{26}$ sowel as om te verlos ${ }^{27}$. Sy grootheid en mag is nie afhanklik van ondersteuners of van hulle belydenis oor Hom nie, maar is in Homself gesetel (1:9; $14: 24 ; 44: 6-8)$.

\subsection{Skepper en Verlosser}

Daar word besondere klem gelê op God as Skepper. ${ }^{28}$ Veral in die tweede deel van die boek word dit sterk gekoppel met sy verlossingswerk 29 en wat met die benaming Verlosser (לאג) ${ }^{30}$ So word God se almag sowel as sy reddende optrede verkondig en bely. ${ }^{31}$

God word in die tweede deel van Jesaja nie net gesien as iemand wat by die begin geskep het nie maar ook as iemand wat nou skep en in die toekoms sal skep (48:7; vgl. ook Beuken, 1979:168 i.v.m. 43:7). Sy skeppende optrede word ook op die geskiedenis

Ek is die eerste en $E k$ is die laaste, buiten My is daar geen God nie; 6:5: "En nou het ek die Koning gesien, die Here die Almagtige"; 47:4: "Ons Verlosser is die Heilige van Israel sy Naam is dic Here die Almagtige."

${ }^{26} \mathrm{Vgl} .3: 8 ; 5: 9,16 ; 9: 12 ; 14: 24$.

$271: 9 ; 8: 18 ; 44: 6 ; 54: 5$, ens.

${ }^{28}$ Byvoorbecld $4: 5 ; 22: 11 ; 27: 11 ; 29: 16 ; 40: 12-26 ; 41: 20 ; 42: 5 ; 43: 1,7,15 ; 45: 7,8,12,18 ; 54: 16 ; 57: 19 ;$ 65:17,18.

${ }^{29}$ Bywoorbeeld 40:12-26 vgl. v. 27-29; 42:5-7; 43:1,7,15; 44:2; 45:18,21; 54:5; 65:17; 66:22.

30 Vergelyk bv. $41: 14 ; 43: 14 ; 44: 6,24 ; 47: 4 ; 48: 17 ; 49: 7,26 ; 54: 5 ; 60: 16 ; 63: 16$

31 17:7: "Daardie dag sal die mens weer sy hoop op sy Maker vestig, sy hulp van die Heilige van Israel verwag"; 40:28,29: "Weet jy dan nie, het jy nog nie gehoor nie? Die Here is die ewige God, Skepper van die hele aarde, Hy word nie moeg nie, Hy raak nie afgemat nie en sy insig is ondeurgrondelik. Hy gee die vermocides krag, Hy versterk dié wat nie meer kan nie"; 37:16,17: "Here, Almagtige, God van Israel, $U$ wat oor die gerubs troon, $U$ alleen is God oor al die koninkryke van die aarde, $U$ het die hemel en die aarde gemaak. Hoor tog, Here, luister; kyk tog, Here, let tog op!" 
betrek. In hierdie opsig het God se werksaamheid om te "skep" in die tweede deel van Jesaja 'n soteriologiese aard (vgl. Bernhardt, 1973:775; Von Rad, 1962:137,138; 1965:240,241).

Dit beteken egter nie dat God se optrede in hierdie verkondiging heeltemal soteriologies is in die sin dat God se skeppende optrede in diens van verlossing staan nie. Sy skeppende optrede in die sin van sy verlossende optrede word dan ook alleen op Israel betrek $(43: 1,7,15)$ en nie op die ander nasies nie. Wel word verkondig dat Israel se posisie, synde in ballingskap wees, so verlore is dat alleen God uitkoms kan bewerk, en wel deur ' $n$ wonderbaarlike optrede in die hele wêreldgeskiedenis deur as't ware 'n nuwe skepping tot stand te bring. Israel se verlore posisie vestig dus die aandag op God se hoedanigheid as Skepper. Omdat Hy Skepper is, kan Hy red. Ons sou kon sê Hy kan "herskep", Hy is die Skepper van hemel en aarde, die Regeerder, die enigste en onvergelyklike God; daarom kan sy volk in hulle hulpeloosheid op Hom vertrou vir nuwe krag (40:12-26). Hierdie vertroue en belydenis kom nie uit hulleself nie inteendeel, dit is God wat hulle aandag daarop vestig, juis omdat hulle mismoedig is deurdat hulle nie hierdie feit in gedagte hou nie $(40: 27,28)$.

Dit gaan ten diepste daarom dat erken sal word dat Hy Jahwe is, en dit beteken nie bloot dat Hy verlossing bewerk nie, maar dat alleen $\mathrm{Hy}$ God is, ${ }^{32}$ dat alleen Hy die gebeurtenisse en die gang van die geskiedenis bepaal en selfs vooraf aankondig. 33

\subsection{God van Jakob/Israel}

God verwys na Homself met hierdie benaming. ${ }^{34}$ Ook die volke en die profeet gebruik dié benaming vir God. 35

\footnotetext{
$3243: 12,13 ; 44: 6-8 ; 45: 6,21-23 ; 46: 9$.

$3345: 1,7,21 ; 46: 9,18 ; 48: 3-11$.

4 17:4-7: "Daardie dag sal Jakob se mag onbeduidend word en sy voorspocd sal verdwyn ... As daar nog iets agterbly om te oes, sal dit wees soos nadat olywe afgeslaan is ... sê die Here die God van Israel. Daardie dag sal die mens weer sy hoop op sy Maker vestig"; 41:17: "Die hulpeloses en die armes soek water, maar daar is nie; hulle versmag van dors. Maar Ek, die Here, sal hulle gebede verhoor; Ek, die God van Israel, sal hulle nie verlaat nie". 60:16: "Dan sal jy besef dat Ek die Here is, jou Redder, dat die Magtige van Jakob jou Verlosser is."

35 2:3: "Baic volke sal daarheen (na Jerusalem toe) gaan en sê: 'Kom, laat ons optrek na die berg van die Here toe, na die huis van die God van Jakob, sodal Hy ons sy wil kan leer, en ons daarvolgens kan lewe ..."; 45:15: " $U$ is die God wat $U$ verborge hou, die God van Israel, die Redder!" Kyk ook 1:24; 17:6; 21:10,17; 24:15; 29:23; 37:16,21; 41:17; 45:3,15; 48:1,2; 52:12.
} 
Hierdie benaminge wys op God se noue verhouding met sy vereerders, sy betrokkenheid by hulle en op hulle vertroue in sy reddende mag en teenwoordigheid. Dit is ook uit die gebruik van die benaminge in Jesaja duidelik dat Hy nie die God van Jakob/Israel is op grond van hulle inisiatief omdat hulle Hom as God aangeneem het en Hom bely nie, maar dat hierdie verhouding en belydenis oor Hom ten volle die vrug van sy inisiatief is. Dit blyk byvoorbeeld daaruit dat Hy Jakob/Israel "geskep" het (vgl. Young 1972b:138 i.v.m. 43:1; hierdie "skep" wys eerstens op die uittog uit Egipte, die woestynreis en intog in Kanaän (Westermann, 1966:96)).

\subsection{Die Heilige van Israel}

Hierdie naam bind die boek saam en kom agt en twintig keer daarin voor, en slegs vyf keer elders in die Ou Testament. Die naam staan nie soseer afgrensend teenoor die ander benaminge en omskrywinge van God in Jesaja nie maar vat saam wat hulle tot uitdrukking wil bring ( $\mathrm{vgl}$. Helberg, 1988a:70,71). Daarom is hierdie naam wat in die boek Jesaja tiperend is van die verhouding tussen God en Israel van wesenlike belang om die verhouding van belydenis tot openbaring in hierdie boek te bepaal.

God self verkondig Hom met hierdie naam ${ }^{36}$ en God word deur die profeet deur dié naam bely. ${ }^{37}$ Ook goddeloses, hulle wat hulle vaswoel in die bande van ongeregtigheid, gebruik dié benaming 38 - so ook gebruik Sion se vroeëre verdrukkers dié benaming. ${ }^{39}$

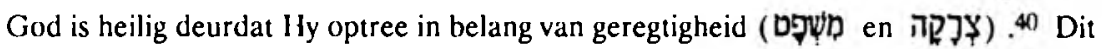

\footnotetext{
361:4: "Ellende wag vir julle, sondige nasie, volk met skuld belaai, geslag wal verkeerd handel; julle wat net afbreek; wat My, die Herc, verlaat het; My, die Heilige van Israel verag en vir My dic rug gedraai het"; 41:14: "Moenie bang wees nic, al is jy niks meer as 'n wurm nie, Jakob; al is jy klein, Israel. Ek hclp jou, sê die Here jou Verlosser, die Heilige van Israel."

3731:1: "Ellende wag vir dié wat by Egipte hulp gaan vra; hulle verlaat hulle op perde, hulle is vol vertroue as daar baic strydwaens is, as hulle oor 'n menigte ruiters kan beskik; maar op die Heilige van Isracl vertrou hulle nic, na dic wil van die Here vra hulle nie"; 47:4: "Ons Verlosser is dic Heilige van Isracl, sy Naam is dic Here dic Almagtige."

385:19: "Hulle sê: Hy moet gou maak, Hy moet sy werk gou doen dat ons dit kan sien! Wat die Heilige van Isracl wil doen, moet gou gebeur dat ons dit kan weet."

${ }^{39}$ 60:14: "Hulle sal jou noem: Stad van dic Here, Sion van dic Heilige van Israel."

405:16: "Die Here die Almagtige is verhewe. Hy laat reg geskied (DSWD); die Heilige laat Hom ken as die Heilige, Hy oordeel regverdig (דִ
} 
dui onderskeidelik op sy straffende hoedanigheid maar ook sy verlossende optrede. ${ }^{41}$ Die feit dat God "die Heilige van Israel" genoem word, benadruk sy besondere verhouding met sy volk. God bestaan nie in geïsoleerdheid of abstraktheid nie maar kan geken word aan sy verhouding met Israel, en wel hoe $\mathrm{Hy}$ in daardie verhouding optree: straffend en verlossend. Die naam "die Heilige van Israel" is dus nie 'n bloot kultiese begrip wat God se hoedanigheid en vereistes in verband met die kultus en die aanbidding daar uitdruk nie, maar is veral religieus-sedelik-histories.

Daar is 'n spanning, selfs 'n paradoks in die naam (vgl. ook Beuken, 1979:82; Elliger, 1978:151,152; Kaiser, 1970:60,61). Die "Heilige" is Hy wat verhewe is bo alles wat menslik is; Hy wat in sy goddelikheid nie benaderbaar is nie. ${ }^{42}$ Hy het egter die wonder gedoen om Homself aan Israel te verbind. Hy tree op selfs teen die grein van die gebeurtenisse en omstandighede in, selfs teen die verkeerde gesindheid van sy volk in. Hy doen die onmoontlike: bewerk lewe uit materiële, liggaamlike en geestelike ondergang en dood. ${ }^{43}$ Dié naam word dan ook dikwels sinoniem met "Verlosser" gebruik. ${ }^{44}$ As die Heilige van Israel gaan sy gedagtes en sy optrede oor verlossing die mens se begrip te bowe en bewerk sy woord verlossing. ${ }^{45}$ Alles is verniet, net genade 46; tog word die beroep op die mens se verantwoordelikheid tot bekering en 'n lewe ten volle in God se diens onverswak en dringend gestel. ${ }^{47}$ Die naam impliseer dus 'n wedersydse verhouding tussen God en sy volk, 'n verhouding waarin alle inisiatief by God is maar waarin Hy die regte optrede van sy volk eis. Hy is die absolute Regeerder oor sy volk se doen en late maar staan tegelykertyd in 'n persoonlike verhouding met hulle waarin hulle die verantwoordelikheid het om volgens sy wil te leef en om Hom te bely.

\footnotetext{
${ }^{41} 1: 4 ; 5: 19,24 ; 17: 7 ; 30: 12,15 ; 31: 1 ; 37: 23 ;$ en $10: 20 ; 12: 6 ; 29: 19,23 ; 41: 14,16,20 ; 43: 3,14 ; 45: 11 ; 47: 4$; $48: 17 ; 49: 7 ; 55: 5 ; 60: 9,14$.

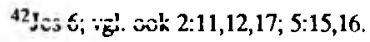

${ }^{43} 1: 10 ; 6: 11-13 ; 11: 1,2 ; 26: 14-19 ; 40: 6-11,28,29$.

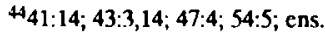

4555:6-11.

${ }^{46} 55: 1-3$

4755:6-8
} 


\subsection{Jahwe}

God word ook Here (Jahwe) genoem. Hieroor sal egter in 4.1 en in 5 gehandel word. Die verkondiging van die boek Jesaja trek saam in die benaminge "die Heilige van Israel" en "Jahwe".

\section{DIE GROND EN DRYFVEER}

Die grond en dryfveer van belydenis in Jesaja is God se inisiatief in alles - ' $n$ inisitaief wat onder meer duidelik word in die Goddelike selfbekendstelling.

\subsection{Goddelike inisiatief}

Die Goddelike inisiatief beheers die hele boek Jesaja. Die boek begin met hoe swaar die verbondsvolk kry en sê dat dit God is wat dit aan hulle doen, dit is sy straffende optrede (1:2 e.v.). In 2:12-22 word die dag van die Here, die skrikwekkende dag van afrekening aangekondig.

Israel se swaarkry is nie toevallig nie en word nie bloot deur ander nasies oor hom gebring nie. Hierdie feit kom duidelik na vore wanneer Israel in die verlorenheid van ballingskap verkeer, wanneer dit lyk of God'n swygende en passiewe God is, wanneer Israel in sy gevoel van verlatenheid uitroep: "Die Here sien nie raak wat van my word nie, my reg gaan by my God verby!" (40:27). Dan wys God dat Hy in beheer van dit alles is, dat Hy die Skepper alles regeer en bepaal. Ook is Hy die Verlosser (40:12-26). Dit mag skyn asof Hy passief of afwesig is, maar die werklikheid kom na vore in die profeet se belydenis: "U is die God wat $U$ verborge hou, die God van Israel, die Redder" (45:15). Hy gaan Israel in die ballingskap red, Hy alleen, op sy eie inisiatief en met sy wonderdadige optrede - sonder enige bydrae van Israel of enigiemand anders (40:1 e.v.).

Nie alleen in wat Hy doen neem Hy alle inisiatief nie maar ook in wat Hy sê. In hoofstuk 40 is God aan die woord met die aankondiging van die redding. Dit gebeur onverwags, sonder aanleiding of aanloop, selfs sonder dat die profeet of iemand anders sê: "So sê die Here". Dit is 'n onverwagte aankondiging waarin God self, in die direkte rede, aan die woord is. Hierdie inisiatief van God in daad en woord is die grond en dryfveer vir Israel se belydenis. Die belydenis is ten diepste nie iets uit die verbondsvolk of die mens self nie. Israel se belydenis was nie 'n selfstandige inset naas 
die Goddelike openbaring of as wesenlike aanvulling daarvan nie, maar het slegs die Goddelike openbaring beaam. Daar is dus nie sprake van openbaring-en-belydenis nie, maar slegs van die belydenis van wat geopenbaar is. Die mens is selfs nie in staat om die woord van God te verkondig nie maar sit in verleentheid daarmee. Dit blyk uit die verleentheidsantwoord op die oproep in 40:6,7 om die woord te verkondig. ${ }^{48}$ Trouens, juis die verkondiging van die woord het Israel in ballingskap laat beland. Die ballingskap was ' $n$ vervulling van die strafdreiging wat in daardie woord vervat was. Dit is met Israel net so gesteld soos met die mens in die algemeen. Die mens wil uit homself nie die woord gehoorsaam nie en kan dit ook nie doen nie. Verkondiging van die woord en belydenis is vir die mens onmoontlik. Alleen God maak dit moontlik deurdat Hyself na sy volk toe kom in sy wonderbaarlike almag en liefde - so sê die verse wat direk hierop volg. ${ }^{49}$ Hy roep op tot bekering en Hy skenk vergifnis deur sy onpeilbare liefde en deur sy woord wat nie onverrigter sake na Hom toe terugkeer nie (55:6-11). Dit is deur God se vergewende genade dat Israel Hom ken en bely $(1: 3,4,18$; $53: 11)$.

Dit is dus nie uit homself dat die mens in dié verband optree of praat nie. Labuschagne (1976:340) sê dan ook dat dit van groot belang is dat as die mens subjek van "antwoord" (ע) is, dat nie die mens die inisiatief neem nie maar Jahwe - Hy wat roep (Jes. 50:2; 65:12; vgl. ook Jer. 7:13; 35:17; Job 14:15; Miga 6:3). (ענה) beteken nie in die eerste plek om te antwoord nie, maar om te reageer (Labuschagne, 1976:337). Israel se geloof in God het nie sy oorsprong in refleksie nie maar gaan daaraan vooraf (Vriezen, 1966:363). Dié volk het sy God ontmoet as 'n lewende God wat Hom in die geskiedenis van die volk en in die persoonlike lewe openbaar. Israel se hele bestaan, voorspoed en belydenis is ten diepste die vrug van die werking van die Gees $^{50}$ (vgl. ook Elliger, 1978:390).

\footnotetext{
48"Iemand sê: 'Roep!' En ek vra: 'Wat kan ek roep? Alle mense is soos gras, alles waarop hulle st aatmaak, is soos 'n veldblom: die gras verdor en blomme verwelk as dic Here sy wind daaroor laat waai:"

4940:9-11: "Jy wat die gocie tyding moet bring, moenic bang wees nic. Se vir die stede van Juda: 'Julle God is hier! Die Here God kom, Hy is die magtige, Hy regeer ... Soos ' $\mathrm{n}$ herder versorg Hy sy kudde ..." Hierdie verklaring van 40:6-8 en 9-11 los die probleem op wat deur Beuken (1979: 23) geopper word, naamlik dat dit onwaarskynlik is dat die profeet sou vra wat hy moct gaan verkondig, en dat die strekking eerder is: hoc kan ek verkondig. Die profect se probleem is: wat kan ek roep? - gesien die dinamiese en effektiewe( vgl. Muilenburg, 1956:430,431), maar tegelyk vernietigende effek van die woord op dic mens.
}

50 44:3-5: 'Ek sal my Gees uitgiet op jou kinders ... Hulle sal vitspruit soos gras in die veld... Die een sal sé: 'Ek behoort aan die Here', en homself ' $n$ nakomeling van Jakob nocm; dic ander sal op sy hand skrywe: Die Herc s'n en homself 'n lid van die volk Isracl noem." 
Die Goddelike inisiatief blyk ook en veral uit die Goddelike selfbekendstelling.

\subsection{Die Goddelike selfbekendstelling}

Die Goddelike selfbekendstelling kom veral voor in die sogenaamde "Ek is"-uitsprake. Daarin dui God Homself aan as die Een wat absolute mag het om sy wil en sy plan tot verlossing deur te voer. Hierdie selfbekendstelling kom dikwels in die tweede deel van Jesaja voor, is baie sterk aan die naam Jahwe verbind en kom voor in formulerings soos: "Ek Jahwe", "Ek is Jahwe", "Ek, Jahwe jou God", "Ek is Jahwe jou God", en "Ek is dit".51 Van die 54 keer wat ' slegs 6 keer op mense. Daarby kom nog dat אָנ (ek) 15 keer op Jahwe dui en een keer op 'n mens (vgl. Elliger, 1978:140,141). Die uitdrukking kom voor in stellings soos: "Wie het die verloop van dinge van die begin af bepaal? Dit is Ek, Jahwe! Ek is die eerste en wanneer die laaste dinge gebeur, sal Ek nog Jahwe wees" (41:4). Ook die formulering "Ek is dit" staan volgens die verband in die nouste verbinding met die naam Jahwe. 52

Die Goddelike selfbekendstelling kom ook elders in die Ou Testament voor (vgl. hieroor Helberg, 1988b en sy literatuurverwysings). God word nie slegs in die derde persoon voorgestel nie maar Hy kom ook self aan die woord. Hy openbaar Hom nie slegs in of deur die geskiedenis nie. Sy volk kry nie slegs tweedehandse kennis oor Hom nie; Hy is die lewende en teenwoordige God. As God, as Skepper en enigste Regeerder, konfronteer Hy elkeen aan wie Hy Hom openbaar. Die mens kan hierin nie vryblywend wees nie. God se selfbekendstelling eis hom op, lê besłag op hom. Anders as die diere en die res van die skepping is die mens 'n persoon en staan hy in 'n persoonlike verhouding met God. God se beslaglegging op sy volk is daarom nie outomaties nie; Israel reageer nie soos 'n robot wat deur 'n skakelaar beheer word nie. Tog is God se bekendstelling dwingend in die sin dat Hy sy volk tot aksie en belydenis bring. Dit is ten diepste nie Israel wat (reg) antwoord nie, maar God wat dit bewerkstellig. Bowendien is dit 'n korreksie op die reaksie van Israel.

Hoewel die tipiese selfvoorstelling van God in die vorm "Ek is..." nie in 1-39 voorkom nie, is dieselfde elemente wat inhoudelik daarin vervat is, duidelik aanwesig. Dit blyk byvoorbeeld uit die heel eerste hoofstuk waarin God aan die woord is en hemel en

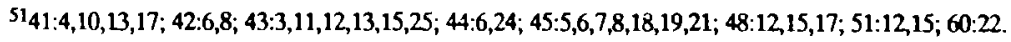

$\$ 243: 25$ vgl. $43: 3,15 ; 48: 15$ vgl. 48:1,2,9,11; 51:12 vgl. 53:13,15.
} 
aarde oproep om getuies te wees van hoe $\mathrm{Hy}$ sy volk tot verantwoording roep en tog redding in vooruitsig stel.

Dit mag lyk of die Goddelike selfbekendstelling in die Ou Testament hierdie stelling loënstraf en selfs die teenoorgestelde leer, aangesien die Goddelike selfbekendstelling nooit by die eerste kennismaking met God voorkom nie maar altyd in aansluiting by wat reeds van God bekend is. Tog kan hieruit nie afgelei word dat die Goddelike selfbekendstelling op die nadenke of beskouing van die volk/gemeente rus nie. Inteendeel, die Goddelike selfbekendstelling sluit aan by wat Gód reeds gedón het en is daarop gegrond. Verder staan dit veroordelend (korrektief) teenoor wat Israel, of die mens doen en bely. ${ }^{53}$ Die aard van God se selfbekendstelling hier stem dus ooreen met dié aan Moses (Eks. 3, vgl. Helberg, 1988a:297,300).

Deur die reddende (52:1 e.v.) en verkondigende optrede (goeie boodskap 52:7) bring God self sy volk daartoe om sy Naam te bely ("ken", ריע). ${ }^{54}$ Dit wat vir Israel en die mens daartoe bring om God te bely, is die uitverkiesende genade van God, sy mag as Skepper, Regeerder en Verlosser, en die lewewekkende werking van sy Gees. ${ }^{55}$

Israel ken homself eers uit God se selfbekendstelling waarin Israel tot dienaar aangewys en gestel word. ${ }^{56}$ Dit is God wat Israel, en so ook iemand anders, sy dienaar maak (vgl. ook 49:3,5); dit is Hy wat sy dienaar leer wat om te sê en hoe om op te tree: die dienaar moet veral luister (50:4).

\footnotetext{
5340:27-31: "Waarom sê jy dan, Jakob, waarom kla jy, Israel: 'Die Here sien nie raak wat van my word nie, my reg gaan by my God verby!' Weet jy dan nie, het jy nie gehoor nic Die Here is die ewige God, Skepper van die hele aarde ... Hy versterk dié wat nic meer kan nie ... dié wat op die Here vertrou, kry nuwe krag."
}

5452:6: "Daardie dag sal my volk my Naam bely: dat Ek Jahwe is, dat dit Ek is wat sê: Hier is Ek!"

55 44:1-4: "Maar luister nou, my dienaar Jakob, Israel wat Ek uitverkies hel: So sê die Here wat jou gemaak het, Hy wat jou gevorm het in die moederskoot en jou nou nog help: 'Moenie bang wees nie, my dienaar Jakob, Jesurun wat Ek vitverkies het. Ek sal volop water gee op die dorsland, strome op die droe grond. Ek sal my Gees uitgiet op jou kinders, my seên op jou nakomelinge. Hulle sal uitspruit soos gras in die veld, soos wilgerbome langs waterstrome. Die een sal sế: 'Ek behoort aan die Here', en homself 'n nakomeling van Jakob noem; die ander sal op sy hand skryf: Die Here s'n en homself 'n lid van die volk van Israel noem", vgl. 44:21-23; 48:12,17-21.

\footnotetext{
${ }^{56}$ Behalwe uit 44:1 blyk hierdie noue verbinding tussen die Goddelike selfbekendstelling en dienaarskap ook uit $41: 8$ vgl. v. 10,13,14, 42:1 vgl. v.5; $44: 21$ vgl. v.6.
} 


\section{DIE FUNKSIE EN DOEL.}

Dit is God se uitgesproke doel dat sy openbaring of verkondiging vir Israel daartoe moet bring om te erken en te bely dat Hy Jahwe is (52:6), en dit is uiteindelik ook die funksie en doel van Israel se belydenis (vgl. ook Childs, 1986:43,44). ${ }^{57}$

"Ek is Jahwe" is in die tweede deel van Jesaja 'n waarborg vir sy verlossende optrede, en dui verder sy uniekheid teenoor die afgode aan $(43: 11 ; 45: 5,6,18 ; 44: 6 ; 46: 9 ; 48: 12$; Noort, 1985:140,141). God word in die tweede deel van Jesaja gesien as God wat die wêreldgeskiedenis in sy hande het. Hy doen alles volgens sy wil en weet dus hoe alles gaan wees (Elliger, 1978:185,498). Jesaja 52:6 verkondig dat Israel die volk sal wees wat sy Naam ken soos in die tyd van die verbond, maar die woorde beteken verder dat die volk sal weet dat hulle God soewerein en almagtig is, dat $\mathrm{Hy}$ die geskiedenis beheers en dat die lot van Israel en die nasies in sy hand is (Muilenburg, 1956:609). Die Naam, anders as by Israel se bure, was nie bedoel as blote instrument in die kultiese aanroeping nie maar as 'n verkondiging van hoop, 'n bevestiging van sekerheid in die krag van die Goddelike voorneme om dit tot vervulling te bring (Terrien, 1978:115). Von Rad (1962:141) wys daarop dat die wêreld en die volk hulle eenheid nie in 'n kosmologiese eerste beginsel het, soos by die Ioniese filosowe nie, maar in die persoonlike wil van Jahwe, hulle Skepper.

In die erkenning of belydenis dat Hy Jahwe is, gaan dit nie om die benaming Jahwe as sodanig nie maar om Jahwe self. Dit gaan om die feit dat alleen $\mathrm{Hy}$ God is, dat Hy die Almagtige is, dat alles om Hom draai en dat Hy die Verlosser is. Dit kom duidelik na vore in 37:20: "Dan sal al die koninkryke van die aarde besef dat net U, Jahwe, God is". Die naam "Jahwe" vervang dan ook nie ander name vir God nie, maar vul hulle aan en word deur hulle aangevul. Die gemeenskaplike aspek in die name is die absoluut teosentriese betekenis (vgl. byvoorbeeld die bespreking van die naam Jahwe soos aan Moses geopenbaar in Eks. 3:12,14,15, by Amsler, 1976:483-486; Jenni, 1971b:701707; Bernhardt, 1975:406,407; Freedman, 1982:545-548; Helberg, 1988b). Daarom kan byvoorbeeld gesê word dat die boek Jesaja deur die naam "die Heilige van Israel" saamgebind word (vgl. 3.8) en tog tegelykertyd dat Jesaja se verkondiging saamtrek in: "... julle/hulle sal besef dat Ek/Hy Jahwe is". Die name staan nie in konkurensie met mekaar nie. Albei name sê dat Hy enig en onvergelyklik is; Hy kan net in terme van

5749:23: "Dan sal jy besef (jd") dat Ek Jahwe is, wie op My vertrou, word nie teleurgestel nie"; 49:26: "Dan sal al wat leef, besef (jd') dat Ek Jahwe is, jou Redder en Verlosser, die magtige God van Jakob"; 52:6: "Daardie dag sal my volk my Naam bely (jd"): dat Ek Jahwe is, dat dit Ek is wat sé: Hier is Ek! (vgl. ook 45:3; 60:16). 
Homself geken word - as Skepper, Regeerder en Verlosser van sy volk. Dié name word ewe gemaklik parallel gebruik: "Julle ... wat My, Jahwe, verlaat het; My, die Heilige van Israel, verag ... het". 58

Dit gaan wel vir God om sy Naam: dat sy Naam aangeroep word, 59 geëer en geloof word, ${ }^{60}$ liefgehê word ${ }^{61}$ en dat op sy Naam vertrou word. 62 God maak vir Hom 'n Naam ${ }^{63}$ en tree op ter wille van sy Naam. ${ }^{64}$ Hierdie Naam is egter nie een bepaalde benaming nie, maar is Hyself. Daarom kan Hy sê dat sy Naam "Jahwe" is, maar ook dat dit "Jahwe Sebaot" (die Here die Almagtige) is, ${ }^{65}$ of "ons Verlosser". 66 Nie die benaming van God as sodanig is dus 'n voorwerp van verkondiging of belydenis nie, maar God self.

God se bekendstelling aan Moses as Jahwe benadruk dan ook dat Hy nie deur 'n naam omvat kan word nie. Hy sê: "Ek is wat Ek is", en: "Ek is" (sinspelinge op : Jahwe; Eks. 3:14,15). Hy word veral geken aan sy beskermende teenwoordigheid by sy volk en sy optrede om hulle te red en om hulle Hom te laat dien (vgl. Helberg, 1988b:294-299). Botterwcck (1982:502) wys dan ook daarop dat die uitdrukking "julle sal besef dat $\mathrm{Ek}$ Jahwe is", byna altyd voorafgegaan word deur 'n uitspraak oor Jahwe se optrede.

Dit is daarom dat dit enersyds in Genesis 4:26 gestel word dat mense die Naam van Jahwe in Enos se tyd begin aanroep het, terwyl andersyds in Eksodus 6:2 gestel word dat God Hom nog nie voor die tyd van Moses met daardie Naam bekend gemaak het nie. Daarom ook dat Psalm 53 die naam God gebruik, terwyl Psalm 14 wat feitlik in sy geheel identies is met Psalm 53, die naam Jahwe gebruik. Die onderskeiding tussen die naam Jahwe, synde 'n eienaam, en ander name soos God (Elohim) en Here (Adonai),

\footnotetext{
${ }^{58}$ Vgl. ook $5: 16 ; 41: 16,20 ; 43: 3,15 ; 45: 11 ; 47: 4 ; 48: 17 ; 49: 7 ; 55: 5 ; 60: 9$.

59 41:25; 64:7.

$6024: 15 ; 25: 1 ; 26: 8,13 ; 29: 23 ; 42: 8 ; 43: 7 ; 48: 11 ; 59: 19$.

${ }^{61} 56: 6$.

6250:10.

${ }^{63} 55: 13 ; 63: 14$.

${ }^{64} 48: 9 ; 66: 5$.

$6_{48: 2 ; 51: 15 ; 54: 5 .}$

6663:16.
} 
synde aanvanklik soortname, het gaandeweg kleiner geword en selfs verdwyn. Dit is omdat God en Here prakties eiename van God geword het, net soos die name by ons ook eintlik soortname is wat eiename geword het en ook die ander betekenisnuanses oorgeneem het. In die Griekse vertaling van die Ou Testament wat ongeveer twee eeue voor Christus ontstaan het, is die naam Jaltwe weergegee met Here (Kurios, 'n vertaling van Adonai; vgl. Freedman \& O'Conner, 1982:554). In die Nuwe Testament kom die naam Jahwe glad nie meer voor nie, maar word Here (Kuplos ) gebruik.

\section{SAMEVATTING EN KONKLUSIE}

Hoewel die verskillende gedeeltes van die boek Jesaja verskeie kenmerke vertoon soos dat God se verlossende optrede in 40 e.v. sterker na vore tree as in 1-39, is dit vir die verhouding van belydenis tot openbaring nie van wesenlike betekenis nie. Die inhoud van die boek vorm ' $n$ eenheid soos saamgevat in die kenmerkende naam vir God: die Heilige van Israel.

In die boek Jesaja word deur God verkondig en deur Israel bely dat alleen Hy God is, die Almagtige, die Skepper van die hemel en die aarde, die Regeerder van die daaglikse gebeurtenisse en die geskiedenis: verlede, hede en toekoms, die Verlosser wat uit stoflike en geestelike nood verlos, sonder menslike inisiatief of bydrae. Hy is genadig, barmhartig en vol liefde en is ' $n$ Vader vir sy volk; Hy het hulle uit genade uitverkies en staan in 'n vertrouensverhouding, 'n verbondsverhouding, met hulle. In hierdie verhouding stel Hy die eis dat sy verbondsvolk sy wil, soos saamgevat in sy gebooie, moet gehoorsaam en hulle van hulle sonde moet bekeer. Die doel van sy optrede is dat Israel en die volke sal besef dat Hy Jahwe is. Dit gaan egter nie om erkenning van die benaming as sodanig nie, of dat Hy juis met dié benaming aangespreek moet word nie, maar om die erkenning dat $\mathrm{Hy} \mathrm{Hy}$ is. Hy is onvergelyklik en kan net in terme van Homself geken word - in terme van die onbegryplike verbintenis met sy verbondsvolk, Hy die Heilige van Israel wat reddend by sy onwaardige volk teenwoordig is. Sy volk moet op Hom vertrou en hulle ten volle in sy diens stel.

Die belydenis dat Hy Jahwe is, beaam slegs die verkondiging deur God en is nie 'n selfstandige inset van die belyers nie. Inteendeel, die Goddelike openbaring gaan selfs teen die verkondiger van die openbaring se ervaring, vermoë en wense in (bv. Jes. 40:68). Menslike belydenis het in Jesaja deur en deur 'n ondergeskikte en dienende plek ten opsigte van die openbaring. Die grond en dryfveer vir Israel se belydenis is wat God doen en sè, sy optrede en sy woord. Die Goddelike inisiatief beheers alles. Israel 
moet veral luister en gehoor gee deur gehoorsaamheid aan God se wil, veral soos vervat in sy gebooie. Israel moet hoor sodat hy God kan ken en erken deur hoe hy lewe en deur God te bely.

Ons kan die bevinding en die betekenis van bogenoemde gedagte vir 'n belydenis in die sin van kerklike belydenisskrifte vandag, soos volg saamvat:

* Belydenis is nie 'n menslike inset of bydrae as 'n teenpool van God se spreke, 'n ander kant van die munt nie, nie 'n byvoeging nie, maar het 'n dienende plek en is slegs 'n beaming van God se openbaring. Dit gaan nie om openbaring-en-belydenis nie. In die lig hiervan moet die uitdrukking in ons kerklike praktyk dat iets beoordeel word op grond van "Skrif-en-belydenis", onder die soeklig geplaas word. Gee dié spreekwyse wel uitdrukking aan die ondergeskikte en dienende plek van die belydenis in verhouding tot die Skrif as afgeslote kanon en enigste norm vir ons geloofslewe? Hou dit voldoende rekening met die reformatoriese benadering teenoor Rome se kanonisering van tradisie of belydenis wat verwoord is in die uitdrukking sola scriptura (die Woord alleen)? Is daar nie 'n gevaar om menslike belydenis tot openbaring te verhef nie, soos wat andersyds die Skrif vandag soms verswak word tot menslike ervaring van die Goddelike openbaring?

- Belydenis gaan oor sê én doen, veral oor God as Skepper, Regeerder en Verlosser, wie se woord en optrede sy volk dwing om gehoor te gee met hulle volle lewe gehoorsaamheid dus wat gestalte kry in belydenis. Belydenis sonder ' $n$ lewe waarin geregtigheid beoefen word, is leeg en waardeloos.

- Dit is veral in lofsegging wat Israel se belydenis na vore kom. Dit beteken nie dat 'n geloofsbelydenis alleen gesing moet word en nie onderteken moet word nie; immers in Jesaja het belydenis ook 'n plek. Aan die ander kant, die feit dat belydenis ' $n$ belangrike plek in lofsegging het, hou in dat die kerklike lofsegging in God se eie spreke gegrond moet wees, net soos die belydenis in Jesaja.

- Die belydenis is nie die vrug van selfstandige menslike nadenke oor God wat iets nuuts tot die openbaring byvoeg nie maar is die neerslag van die nadenke oor God se openbaring, die beaming daarvan. Daarom moet belydenis nie opgaan in menslike beredenering en teen-redenering nie en moet daar nie by die belydenis self gebly word nie; belydenis moet God aan die woord laat kom, sy openbaring, die Skrif. 
- Belydenis is gerig op God, soos ons Hom ken uit sy openbaring. Dit gaan om sy Naam, om wat Hy is soos Hy Hom veral geopenbaar het as Skepper en as Verlosser van sy volk. Dit gaan egter nie om 'n bepaalde benaming as sodanig nie. 'n Godsbenaming as sodanig is dan ook nie 'n voorwerp van belydenis in ons konfessies nie.

* Belydenis in Jesaja gaan oor God wat sy volk stoflik en geestelik verlos sonder enige aandeel van hulle kant. Daarom is daar geen plek vir 'n bevrydingsteologie of -konfessie nie, of vir 'n status quo-teologie of -konfessie nie. Dit gaan om 'n andersoortige ryk, 'n ryk wat deur andersoortige metodes tot stand kom en in stand gehou word. Van hierdie ryk en sy vereistes word in die saligsprekinge of seënspreuke getuig, byvoorbeeld: "Geseënd is dié wat weet hoe afhanklik hulle van God is, want aan hulle behoort die koninkryk van die hemele" (Matt. 5:3).

\section{BIBLIOGRAFIE}

AMSLER, S. 1976. הוְי (In ThWAT, I. p.477-486.)

BARR, J. 1974. Some Old Testament aspects of Berkhof's 'Christelijk Geloof. (In Weerwoord: reactics op dr. H. Berkhof's 'Christelijk (ieloof'. Nijkerk : Callenbach. p. 9-19.)

BERNHARDT, K.H. 1973.

BERNHARDT, K.H. 1975. הָ̣T. (In ThWAT. II. p.393-408.)

BEUKEN, W.A.M. 1979. Jcsaja IIA. Nijkerk : Callenbach (P.O.T.)

BEUKEN, W.A.M. 1983. Jesaja. IIB. Nijkerk : Callenhach (P.O.T.).

BOTTERWECK, G.J. 1982. ע]? (II. ThWAT. III. p.479-512.)

BOTTERWECK, G.J. \& RINGGREN, H. red. 1970. Theologisches Worterbuch zum alten Testament. Stuttgart : Kohlhammer.

BRIGHT, J. 1976. Covenant and promise: the prophetic understanding of the future in pre-exilic Israel. Philadelphia : Wesiminsier.

CHILDS, B.S. 1979. Introduction to the Old Testament as Scripture. London : SCM.

CHILDS, B.S. 1986. Old Testament theology in a canonical context. Philadelphia : Fortress Press.

DEIST, F.E. 1982. The problem of history in Old Testament theology. In OTWSA, 24(81). Papers read at the 24th mecting of "Dic Ou-Testamentiese Werkgemeenskap in Suider-Afrika", p.23-39.)

DELITZSCH, F. 1949. The prophecies of Isaiah. II. Grand Rapids : Eerdmans.

ELLICiER, K. 1978. Deulerojesaja. 40:1-45:7. Neukirchen-Vluyn : Neukirchener Verlag. (B.K. XI 6.)

FREEDMAN, D.N. 1982. JHWH. (In ThWAT. III. p.545-548.)

FREEDMAN, D.N. \& O'CONNER, P. 1982. JHWH. (In ThWAT. Ill. p.548-554.)

HELBERG, J.L. 1983. Verklaring en prediking van dic Ou Testament. Potchefstroom : Potchefstroomsc Teologiese Publikasies.

HELBERG, J.L. 1988a. Die motivering van God se verlossende optrede vir sy volk in die bock Jesaja. (In Prinsloo, W.S. \& Vosloo, W. reds. In mensetaal oor God se Woord. Kaapstad : Lux Verbi. p.61-75.) 
HELBERG, J.L. 1988b. Die selfbekendstelling van God in Eksodus $3 \mathrm{en}$ die betekenis daarvan vir vandag. Koers. 53(3):280-304.

JENNI, E. 1971a. אֶ. (In THAT. I. p.1-17.)

JENNI, E. 1971b. יהוה. (In THAT. Il. p.701-707.)

JENNI, I. \& WESTERMANN, C. red. 1971/1976. Theologisches Handwôrterbuch zum alten Testament. München : Kaiser.

KAISER, O. 1970. Der Prophet Jesaja. Kap. 1-12. Götingen : Vandenhocck \& Ruprecht (A.T.D. 17.)

KNIGHT, G.A.F. 1984. Isaiah 40-55. Servant theology. Grand Rapids : Eerdmans.

LABUSCHAGNE, C.J. 1976. ענה I antworten. (In THAT. III. p. 335-431.)

MUILENBURG, J. 1956. The Book of Isaiah. Chapters 40-66. New York : Abingdon. (I B V.)

NOORT, E. 1985. Het IK-zijn van Jhwh: Over de problematick van de persoonlijke God in de theologie van het Oude Testament. G.T.T., 25(3):132-151.

NORTH, C.R. 1967. The second Isaiah. Oxford : Clarendon.

SCHOTTROFF, W. 1971. ירע crkennen (In THAT. I. p.682-701.)

SCHULT, H. 1976. עDV hören. (In THAT. II. p.974-982.) G.T.T. 85 (3):132-151.

SCOTT, R.B.Y. 1956. The Book of Isaiah. Chapter 1-39. New York : Abingdon (I. B. V.)

SEYBOLD, K. 1984. מלך (In ThWAT IV. p.933-956.)

SMART, J.D. 1967. History and theology in Second Isaiah. London : Epworth.

SNIJDERS, LA. 1969. Jesaja I. Nijkerk : Callenbach. (P.O.T.)

SOGGIN, J.A. 1971. Dל König. (In THAT I. p.908-920.)

TERRIEN, S. 1978. The elusive presence: toward a new Biblical theology. New York : Harper \& Row.

THAT

kyk

JENNI, E. \& WESTERMANN, C. red. 1971/1976. Theologisches Handwörterbuch zum alten Testament. München : Kaiser.

THWAT

kyk

BOTTERWECK, GJ. \& RINGGREN, H. red. 1970. Theologisches Worterbuch zum alten Testament. Stutgart : Kohlhammer.

VAN DER WOUDE, A.S. 1976. X7\ Heer. (In THAT. II. p.498-507.)

VERHOEF, P.A. 1981. Metodiek van die eksegese. Kaapstad : N.G. Kerk-Uitgewers.

VON RAD, G. 1962. Old Testament theology. I. Edinburgh : Oliver \& Boyd.

VON RAD, G. 1965. Old Testament theology. Il. Edinburgh : Oliver \& Boyd.

VRIEZEN, TH.C. 1966. Hoofdlijnen der theologie van het Oude Testament. Wageningen : H. Veenman \& Zonen.

WESTERMANN, C. 1966. Das Buch Jesaja. Kap 40-66. Göttingen : Vandenhoeck \& Ruprecht (A.T.D. 19.)

WESTERMANN, C. 1978. Theologie des alten Testament in Grundzügen. Göttingen : Vandenhoeck \& Ruprechi.

WILDBERGER, H. 1982. Jesaja III. Neukirchen: Vluyn : Neukirchener Verlag. (BKAT XI).

YOUNG, EJ. 1972a. The book of Isaiah. I. Grand Rapids : Eerdmans. (NICOT.)

YOUNG, EJ. 1972b. The Book of lsaiah. III. Grand Rapids : Ecrdmans. (NICOT.)

ZOBEL, HJ. 1989. nIXJY. (In ThWAT. IV. p.876-892.) 